\title{
The water salinization
}

\section{Abstract}

The water salinization is a widespread phenomenon in the world and generally, it is accompanied by salinization of soils. This makes very hard to grow any crops because to irrigate with salt water often destroys crops and fertility of soils. To mitigate such issues, within a geographical area of Sicily involved in such problems and declared at risk of desertification, Giuseppe Ingiaimo applied a special version of RO desalination technology capable to satisfy the full needs of farmers. Results were an increasing of produced quantities more than $100 \%$ and a substantial improvement of quality on every crop. So, applying the proper water treatment technologies the effect of water issues that was facing in that area, was mitigated. Alternative technologies of water remediation was applied to agriculture water when available water, although was not salty, it was polluted by other substances harmful for crops.

Keywords: agricultural desalination, desalinated water, salt water, desalinators for agriculture, salinization of waters, brackish water, salinity of water, irrigational water; fresh water for irrigate, irrigation water, desalinators machines, desalters, salty irrigation water
Volume I Issue 2 - 2014

\section{Giuseppe Ingiaimo}

Water Treatment Expert, INGIAIMO Technologies for agriculture, Italy

Correspondence: Giuseppe Ingiaimo, Water Treatment Expert, INGIAIMO Technologies for Agriculture, Europure, Agrigento Area, B. Greco, 2, Licata, Ag, 92027, Italy, Tel +39 338464096I, Email giuseppe@ingiaimo.com

Received: May 10, 2014 | Published: June 10,2014

\section{Introduction}

Around the world, more and more areas are interested in the water salinization. The phenomena is more evident in coastal areas because the increasing water shortage which is causing the penetration of sea water into internal fresh water reserves transforming them into brackish waters practically unusable for irrigation, for human consumption as well as for industrial use.

But when this happens in areas where intensive crops are present, farmers often prefer to continue irrigation by using such salt waters. In this way, growing quantities of salts are deposed on the soils and this spreads to them the salinization problems. Rain will dissolve the salts from soils and will transport them into the waters increasing their salinity level. Then the cycle can start again.

To irrigate with waters more than $375 \mathrm{ppm}$ of TDS (about $500 \mu \mathrm{S}$ of EC) it is cause of increasing damages and reducing of quantities and quality of production. I believe that only few water available in nature conform to the limits of the above (Table 1). This means that crops generally, are not capable to give the max productivity and the best of quality because of salinity of irrigation water. Then the increasing salinization of water represents a risk for food availability and it is reducing the profitability of farmers work.

For these reasons it is dramatically urgent to be able to offer effective and reliable systems to mitigate the impact of water salinization on the agriculture, especially within the developing countries and where farming represents an important part of local economy.

In this line, very interesting was the experimental application of desalination technologies to brackish waters for irrigation within a Sicilian area involved in serious problems of salinization and recognized under risk of desertification. In such area some Governmental Research Organizations have identified as one of the most effective solution, the desalination of waters both for agricultural and for human usages in 2000s and during that time, the problem was well noted and the first agricultural desalination facilities was installed which already was running from some years.
Table I Damages caused from salt irrigation water

\begin{tabular}{|c|c|c|c|}
\hline Parameters & $\begin{array}{l}\text { No } \\
\text { damages }\end{array}$ & $\begin{array}{l}\text { Increasing } \\
\text { damages }\end{array}$ & $\begin{array}{l}\text { Serious } \\
\text { Damages }\end{array}$ \\
\hline TDS (mg/l) & $<375$ & $375-1500$ & $>1500$ \\
\hline SAR & $<6,0$ & $6,0-9,0$ & $>9,0$ \\
\hline $\begin{array}{l}\text { Root Absorbtion: Sodium } \\
(\mathrm{mg} / \mathrm{l})\end{array}$ & $<70$ & $70-210$ & $>210$ \\
\hline $\begin{array}{l}\text { Root Absorbtion: Chloride } \\
(\mathrm{mg} / \mathrm{l})\end{array}$ & $<142$ & $142-355$ & $>355$ \\
\hline $\begin{array}{l}\text { Root Absorbtion: Boron } \\
(\mathrm{mg} / \mathrm{l})\end{array}$ & $<0,5$ & $0,5-2,0$ & $>2,0$ \\
\hline $\begin{array}{l}\text { Leaf Absorbtion: Sodium } \\
(\mathrm{mg} / \mathrm{l})\end{array}$ & $<70$ & $>70$ & - \\
\hline $\begin{array}{l}\text { Leaf Absorbtion: Chloride } \\
(\mathrm{mg} / \mathrm{l})\end{array}$ & $<106$ & $>106$ & - \\
\hline Sprayer: Nitrates (mg/l) & $<90$ & $90-520$ & $>520$ \\
\hline $\begin{array}{l}\text { Ammonium for Sensitive } \\
\text { Species }(\mathrm{mg} / \mathrm{l})\end{array}$ & $<5$ & $5-30$ & $>30$ \\
\hline $\mathrm{pH}$ & 6,5 & $6,5-8,4$ & - \\
\hline
\end{tabular}

The concept on which was based the technological application, what we are talking about was to adapt the traditional RO desalination to agricultural world by making it perfectly suitable with it. The traditional RO systems in fact, were no suitable with agriculture because of excessive energy consumption, a high cost of maintenance and a complex management of systems which generally, required specialized personnel. 
For all these reasons the research was initiated and experimentation period spans over 30years, resulting into interesting applications to agriculture by desalinating the available well water and after treatment to irrigate with it improving the quality and ultimately increasing the profitability of crops.

The most common case was related to brackish waters with an average TDS of 5000ppm and about $1500 \mathrm{ppm}$ of Sodium. The prevalent presence of Sodium chloride often was coupled with presence of Iron which jointly to ferrobacteria made extremely hazardous to treat those waters by RO.

For this reason, an important goal was to arrange a cost effective treatment for Iron removal suitable to farms. Such pre-treatment is based on preliminary oxidation of Iron by air, sedimentation and a catalytic reaction. This is capable to remove more than $98 \%$ of Iron from water. The remaining Iron is complexed by proper anti scalant chemical within the RO section.

I seen it is preferred to maintain a speed of water below $10 \mathrm{mt} /$ hour in filtering device for an effective removal of Iron. In this way I applied the RO technology to desalinate brackish waters for irrigation use. The first application was made to nurseries which was not able to continue their activity without freshwater. The first of these desalination systems is running on regular basis since 1998 and it is currently working.

After the nurseries, desalination systems was installed in agrifarms specialized in greenhouse crops and it was noted further that irrigating with desalinated water, has doubled the production and the quality has improved consistently (Figure 1). The interested farms are involved in farming of various vegetables like tomatoes, melons, cucumbers, peppers, water melons, zucchini, eggplants and flowers.

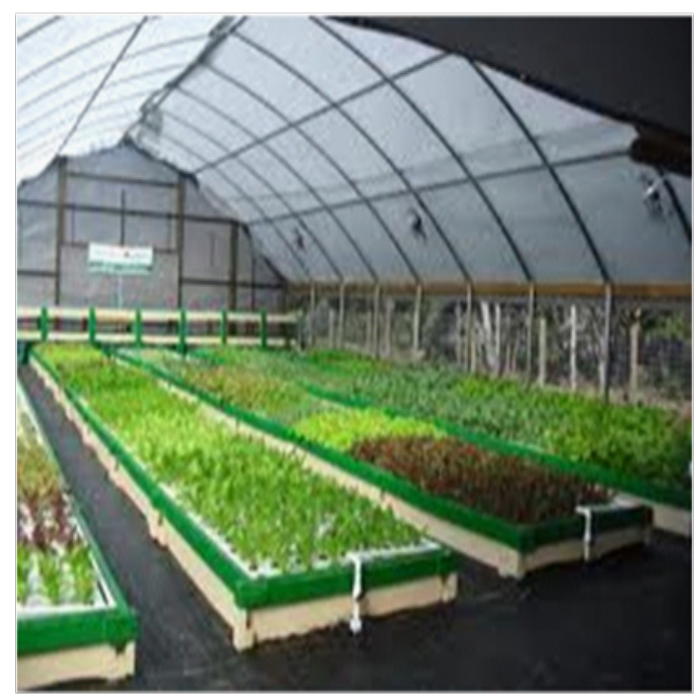

Figure I A generic nursery.

At last, some desalination units were installed specifically for field crops especially in growing of table grapes and artichokes. Encouraging results were obtained, as there was improvement the production of crops in the state. However, here before irrigation, desalinated water was mixed with raw water to obtain a mix with TDS of about 100-1200ppm.

Based on experience, it is possible to confirm that if properly modified, a RO desalination system can fulfill the farmer's needs and it can represent an excellent method to secure good quality irrigation water. Such compatibility will increase if brackish waters have to be treated and will reduce in case of sea water. This means that through proper devices, desalination of brackish water can be considered a technique applicable on regular basis for some crops. The sea water desalination instead, can be considered only as emergency irrigation resource.

More specifically brackish water desalination can be considered ordinary application exclusively to high return crops. Some successful examples include:
i. Nurseries
ii. Flowers
iii. Greenhouse vegetables
iv. Fruits
v. Grapes

For low return crops, such desalination can be applied only as "emergency irrigation" resource. Main features of agricultural desalination from brackish water: (Figure 2).

Range of size: from 5 to $35 \mathrm{mc} / \mathrm{h}$

Feed water TDS: up to $10000 \mathrm{ppm}$

Rejection of salinity: up to $95 \%$

Recovery of water: up to $75 \%$

Energy consumption: from 1,5 to $1,0 \mathrm{kWh} * \mathrm{mc}$

Life cycle of plants: unlimited

Life cycle of membranes: at least 5years

Overall cost of produced water: from $0,2 €^{*} \mathrm{mc}$

Specialized personnel: not required

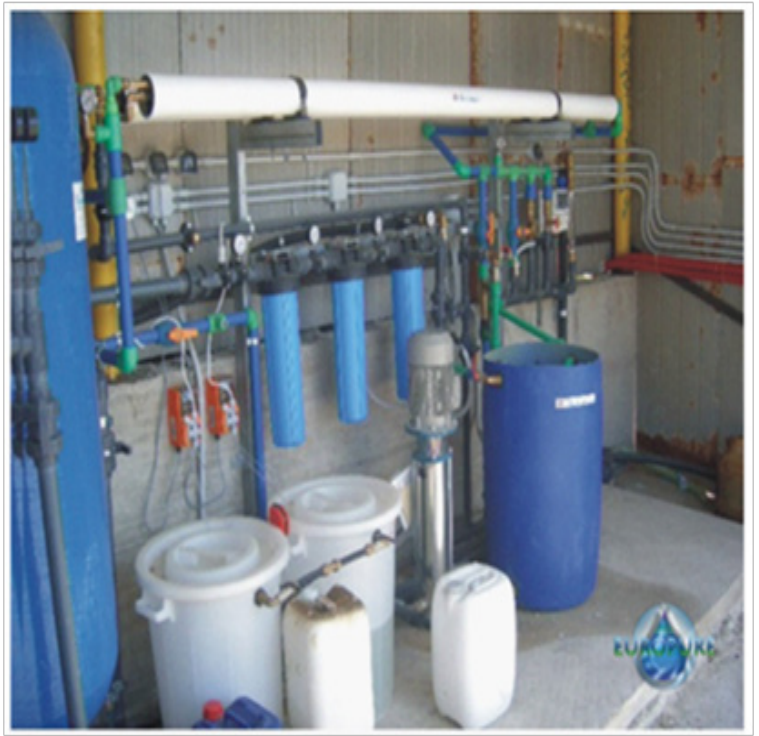

Figure 2 An agricultural desalination system based on INGIAIMO's Technologies. 


\section{The alternatives to desalination}

Some water, although they aren't salty, but contain some specific pollutants and are thus not used for irrigation. If these contaminants are alone present in water, it is better not to use a desalination equipment to improve its quality but proceed for a selective removal of specific pollutant. This allows achieving cost effective measure both as plant purchasing and as maintenance costs.

\section{Selective sodium removal}

When irrigation water cannot be used due to high level of sodium and chloride, it is possible to solve the problem without desalination, by installing a special filtering system capable to remove up $45 \%$ of sodium per pass and $50 \%$ of chloride per pass. Such filters have to be regenerated with proper chemicals.

\section{Selective iron and manganese removal}

One of problems in water is excess of iron (and manganese), which is tolerated up to $5 \mathrm{ppm}$, but at $0.5 \mathrm{ppm}$ it already causes damages to irrigation activities. Already at $0.5 \mathrm{ppm}$ in fact, thanks also the development of iron bacteria, the iron causes clogging at drip systems, to sprayers and to pipes and causes scale and spots on the foliage. For this reason, removal of iron is an important field of irrigation water treatment. Our equipment and devices for iron and manganese removal, allow removing totally these contaminants with an extremely cheap cost.

\section{Selective calcium and magnesium removal}

Another important problem of irrigation water is the calcium and magnesium presence. Even in this case it is possible to adopt cost effective treatments based on ion exchange resins capable to remove totally the hardness from water when it is dangerous for crops.

\section{Arsenic removal}

Arsenic is an element very well known as toxic and it is present in environment, including the underground waters. It is suggested that arsenic presence in water for more than $10 \mu \mathrm{g} / \mathrm{lt}$, needs to be treated in for reducing the level of pollutant. There are available devices, very affordable and extremely effective and they can remove the arsenic from water working as a simply filtering unit. The column in fact, is charged by a special product having this property and it requires only a periodical counter washing by normal water. It will be required replace the filling material time by time depending from water analysis (Figure 3).

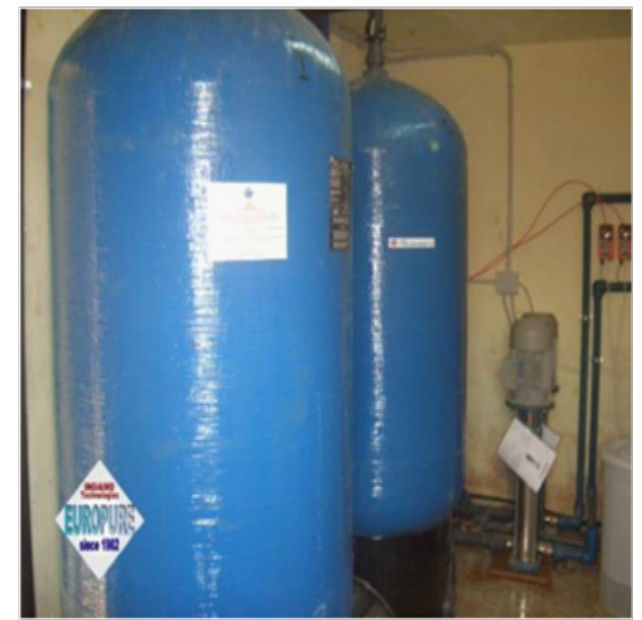

Figure 3 Two iron-manganese removal units for agricultural usage.

\section{Advantages to irrigate with treated water}

Only the farmers that already use a treatment plant know well the advantages of the irrigation with treated water compared to that made with raw water.

Only to give you some idea we can list the main of these:

i. Improved health of crops and increased quantity of products

ii. Improved quality of products

iii. Consistent reduction in irrigational water consumption

iv. Preservation of soils which will not lose their fertility

v. Reduction in fertilizing consumption

This means that if you have salt, high sodium level, iron or other contaminated water, by treating such water you will be able to save money and moreover, you will be able to obtain more results from your crops. Instead, if you don't treat such water and you irrigate with it, you are throwing your money out of the window.

\section{Acknowledgements}

None.

\section{Conflict of interest}

The author declares no conflict of interest. 